\title{
Energetic cost of standard activities in Gurkha and British soldiers
}

\author{
S. S. STRICKLAND* AND S. J. UlIJASZEK† \\ *Centre for Human Nutrition, Department of Public Health and Policy, London School of Hygiene and \\ Tropical Medicine, and Department of Anthropology, University College London, UK and †Department \\ of Biological Anthropology, University of Cambridge, UK
}

Received 20 January 1989; revised 11 June 1989

\begin{abstract}
Summary. Measurements of basal metabolic rate and energy expenditure at lying, sitting, standing, and performing a step test at four levels of exercise, were made on Gurkha soldiers stationed in Britain and on British controls matched by body weight and occupational background. There was no significant difference in basal metabolic rate (BMR), nor in the energy cost of lying, sitting and standing between the two groups. Gurkhas showed significantly lower gross and net energy expenditure, and so significantly greater net mechanical efficiency, at the lower levels of step exercise. The ratio of gross energy expenditure to BMR was lower in Gurkhas at the lowest rates of stepping compared with the British controls. These results suggest that the energy cost of some physical activities expressed as multiples of BMR may not be constant across populations.
\end{abstract}

\section{Introduction}

Recent proposals for estimating total energy requirements acknowledge that a major component is contributed by basal metabolism and advocate expressing physical activity as multiples of basal metabolic rate (BMR) (FAO/WHO/UNU 1985). This view is based on two assumptions: first, that the energetic cost of physical activity correlates with BMR so that for any group of subjects of a given physical activity pattern inter-individual variability in total energy expenditure is reflected in that of their BMR (Shetty and Soares 1988). Second, that while BMR can, for reasons of simplicity, be predicted from body weight using linear equations specific for age and sex, the multiple of BMR applying to a given physical activity does not vary with body weight nor with ethnic background. This paper uses data from a study of standard activities in Gurkhas to explore the latter assumption.

While the question of ethnic differences in BMR is still under investigation (Henry and Rees 1988), and a report of findings on Gurkha BMR has been presented elsewhere (Ulijaszek and Strickland 1989), there is some evidence suggesting that there are ethnic differences in the energy cost of standard activities. Thus, energy expenditure at lying, sitting, and standing is reported to be lower in Africans and Asians living in Britain compared with Europeans, in subjects matched by falling within ranges of height $(165-175 \mathrm{~cm})$, weight $(63-75 \mathrm{~kg})$, and $\mathrm{W} / \mathrm{H}^{2}\left(20-26 \mathrm{~kg} \cdot \mathrm{m}^{2}\right)$ (Geissler and Aldouri 1985). There is also evidence suggesting that African women supporting loads with their heads may carry an initial extra $20 \%$ of body weight at no added energetic cost, perhaps by minimizing the vertical movement of the load, in contrast to untrained subjects whose energy expenditure increased proportionally to the additional mass (Maloiy, Heglund, Prager, Cavagna and Taylor 1986). Neither of these studies, however, reports BMR; and the subjects were not matched individually with controls. In a separate investigation, energy expenditure at walking and stepping showed a linear relation to body weight in Asians and Europeans; and precision of predictions from body weight was not increased by controlling for height, age, sex, race, or resting metabolism (Mahadeva, Passmore and Woolf 1953). 
The case for arguing that there are ethnic differences in the energy cost of standard activities, and that where these exist they reflect differences in basal metabolism, therefore appears unproven. The present study describes measurements of energy expenditure at standard activities, including an incremental step test, on Gurkha soldiers stationed in Britain and on British controls of similar occupation matched by body mass. The argument is that ethnic differences in the energetic cost of standard activities depends partly on differences in muscular efficiency and level of movement of body mass rather than reflecting variation in basal metabolic rate; and that consequently if multiples of BMR applying to a given type of physical activity vary with body weight, then they may do so according to relationships which can differ with ethnic background.

\section{Methods}

Twenty Gurkhas were selected randomly, 5 for each quartile of $\mathrm{W} / \mathrm{H}^{2}$, from a group of fifty all belonging to the Gurung tribe. British controls, also from the 5th Airborne Brigade, were selected to match the Gurkhas by body weight $(< \pm 1 \mathrm{~kg})$. Three Gurkhas of low body weight could not be matched with controls, so data for 17 matched pairs were collected. All subjects were healthy, and aged between 18 and 33 years. BMR was measured for 15 minutes after 11 hours' overnight fast on waking in bed in the barracks medical ward between $04 \cdot 30$ and $07 \cdot 00$. Oxylog portable oxygen consumption meters modified for low flow rates were used (McNeill, Cox and Rivers 1987). It was not possible to standardize all measurements for time of day; therefore according to a prearranged schedule convenient to the men and their employer, measurements of oxygen consumption were made during the day at lying, sitting, and standing quietly, after 30 minutes' rest, each measurement lasting 10 minutes. These were followed by an incremental step test, performed on a double-riser 18-inch step at rates of 15, 20 and 25 ascents per minute, and on a single-riser 18-inch step at 30 steps per minute, for 5 minutes at each rate of work during which oxygen consumption was measured using Oxylogs. Subjects were asked to pace themselves against a timing device. The step tests were discontinuous, with about 1 minute's pause between each test. Anthropometric measurements were made by one trained investigator (Ulijaszek) according to standard methods (Weiner and Lourie 1981).

Although BMR measurements were obtained for all subjects, several other metabolic measurements were rejected. Reasons for rejecting these included: leaking mouthpiece assembly, slipping nose-clips, and a number of technical faults with Oxylogs. As a result, of 15 remaining matched pairs of subjects, satisfactory estimates were obtained for 11 pairs at lying, sitting, and standing; and for 15, 13, and 10 matched subjects for stepping rates 15 and 20,25 , and 30 ascents per minute respectively. Anthropometric data and BMR are therefore presented for the group of 15 paired subjects.

Values for oxygen uptake were derived as the mean of the final 5 minutes of measurements for BMR, lying, sitting, and standing. Estimates for the step tests were derived as the mean of the final 3 minutes of measurements, or 2 minutes in the case of 5 instances in which subjects wished to stop after 4 minutes' stepping. The difference between oxygen uptake at the third and at the final minutes of exercise $\left(\mathrm{VO}_{2(5-3)}\right)$ was used as an index of attainment of steady state (Whipp and Wasserman 1972). It has been argued that these estimates are best presented in terms of heat production, since the error introduced by assuming that the volume of inspired air equals that of expired air is approximately cancelled out by the error of assuming a constant heat equivalent 
of oxygen uptake over the normal range of respiratory quotients (McLean 1984); and in this paper results are generally presented in terms of heat production using the equivalence $20 \cdot 9 \mathrm{~kJ}^{-\mathrm{LO}_{2}}{ }^{-1}$.

Earlier studies recommend calibration of individual Oxylogs (Harrison et al. 1982; McNeill et al. 1987). For the 2 instruments used for all estimates of BMR, lying, sitting, and standing energy expenditure, and for the step tests in the British subjects, the calibration factors published for the same instruments by McNeill et al. (1987) were used. The SEM per cent error in corrected energy expenditure is estimated at $\pm 2 \%$ and $\pm 2.7 \%$ for these two Oxylogs, a level of reliability acceptable under most field conditions (McNeill et al. 1987). A third Oxylog (kindly lent by the Army Personnel Research Establishment, Farnborough), was also used during the step tests on Gurkhas. The flow meter of this instrument was calibrated by drawing a continuous air flow through a Hastings mass flow meter (MFM) and through the Oxylog, so as to simulate inspiratory volume. Measurements were made for 5 minutes at each flow rate over the range $10-150 \mathrm{~L} \cdot \mathrm{min}^{-1}$ with increments of $10 \mathrm{~L} \cdot \mathrm{min}^{-1}$. With the MFM as standard, this instrument tended to overestimate inspiratory volume (STPD) on average by $8.4 \%$. The relationship between estimates was linear and a correction factor was therefore derived as the reciprocal of the slope of the linear regression of the Oxylog's estimate on the standard $(y=1.614+1.047 x, r=1 \cdot 000)$. The inspiratory volumes corrected by this factor $(0 \cdot 955)$ showed an error of $3 \cdot 5 \pm 1 \cdot 1 \%(\mathrm{M} \pm \mathrm{SE})$. This factor was subsequently applied to the oxygen consumption estimates of this instrument. During the calibration tests, it was not possible to conduct recovery trials for the whole system as recommended (McLean and Tobin 1987). Thus it is assumed that any additional error introduced by the polarographic oxygen sensors in the Oxylog is insignificant.

Statistical analysis of the results is by paired $t$ test and linear regression. The difference between the slopes of regressions for two groups was tested for significance by using the $t$-distribution and a pooled estimate of the residual variance as described by Armitage (1971).

\section{Results}

Although it was intended to examine the effects of body size on metabolic efficiency and costs of work, Gurkhas and British subjects were matched closely only by body weight. The Gurkhas were significantly shorter, with higher body mass index $\left(W / H^{2}\right)$, slightly older, and with larger mid calf and upper thigh circumferences (table 1). The difference in the sum of four skinfold thicknesses was not significant. There was no significant difference between the estimates of BMR.

Table 1. Physical characteristics of Gurkhas and British controls $(M \pm S E)(n=15)$

\begin{tabular}{|c|c|c|c|}
\hline & Gurkha & British & Paired $t$ test \\
\hline Age (y) & $25 \cdot 1 \pm 0 \cdot 8$ & $22 \cdot 3 \pm 0 \cdot 8$ & $p<0.05$ \\
\hline Weight (kg) & $67 \cdot 6 \pm 1 \cdot 2$ & $67 \cdot 4 \pm 1 \cdot 2$ & \\
\hline Height $(\mathrm{cm})$ & $167 \cdot 1 \pm 1 \cdot 0$ & $173 \cdot 7 \pm 1 \cdot 6$ & $p<0.01$ \\
\hline Leg length $(\mathrm{cm})^{*}$ & $78 \cdot 1 \pm 0 \cdot 9$ & $83 \cdot 0 \pm 1 \cdot 1$ & $p<0.02$ \\
\hline $\mathrm{W} / \mathrm{H}^{2}\left(\mathrm{~kg} \cdot \mathrm{m}^{2}\right)$ & $24 \cdot 2 \pm 0 \cdot 4$ & $22 \cdot 5 \pm 0 \cdot 4$ & $p<0.01$ \\
\hline Sum 4 skinfolds $(\mathrm{mm})^{\dagger}$ & $39 \cdot 4 \pm 2 \cdot 8$ & $32 \cdot 5 \pm 2 \cdot 1$ & \\
\hline Upper thigh circumference $(\mathrm{cm})$ & $55 \cdot 1 \pm 0 \cdot 6$ & $53 \cdot 5 \pm 0 \cdot 6$ & $p<0.05$ \\
\hline Mid calf circumference $(\mathrm{cm})$ & $37 \cdot 6 \pm 0 \cdot 5$ & $35 \cdot 5 \pm 0 \cdot 4$ & $p<0.001$ \\
\hline $\operatorname{BMR}\left(\mathrm{kJ} \cdot \mathrm{kg}^{-1} \cdot \mathrm{d}^{-1}\right)$ & $106 \cdot 1 \pm 3 \cdot 3$ & $104 \cdot 9 \pm 4 \cdot 8$ & \\
\hline
\end{tabular}

$\bar{*} n=14$ due to misrecording of one individual's measurement. ${ }^{\dagger}$ Biceps + triceps + subscapular + suprailiac. 
Table 2. Energy cost of lying, sitting, and standing, and of stepping at different rates (kJ.min ${ }^{-1}$; $\mathrm{M} \pm \mathrm{SE})$

\begin{tabular}{lrrr}
\hline Activity $(n)$ & Gurkha & British & Paired $t$ test \\
\hline Lying (11) & $5 \cdot 6 \pm 0 \cdot 3$ & $5 \cdot 5 \pm 0 \cdot 2$ & \\
Sitting (11) & $6 \cdot 3 \pm 0 \cdot 4$ & $5 \cdot 9 \pm 0 \cdot 2$ & \\
Standing (11) & $6 \cdot 7 \pm 0 \cdot 4$ & $6 \cdot 8 \pm 0 \cdot 2$ & $p<0 \cdot 01$ \\
15 steps/min (15) & $27 \cdot 1 \pm 1 \cdot 7$ & $36 \cdot 2 \pm 1 \cdot 4$ & $p<0 \cdot 01$ \\
20 steps/min (15) & $37 \cdot 6 \pm 1 \cdot 7$ & $46 \cdot 4 \pm 1 \cdot 5$ & $p<0 \cdot 05$ \\
25 steps/min (13) & $51 \cdot 2 \pm 1 \cdot 7$ & $56 \cdot 4 \pm 1 \cdot 7$ & \\
30 steps/min (10) & $50 \cdot 8 \pm 3 \cdot 6$ & $58 \cdot 5 \pm 1 \cdot 7$ & \\
\hline
\end{tabular}

Estimates of energy expenditure at lying, sitting, and standing also showed no significant differences between the two groups (table 2). The anthropometric and age differences between the groups, however, make straightforward comparison of metabolic efficiency questionable, and it is useful to examine the estimates for the exercise tests and a number of derived variables.

Table 3. Difference in energy expenditure between third and final minute's exercise at different rates of work $\left(\mathrm{kJ} \cdot \mathrm{min}^{-1} ; \mathrm{M} \pm \mathrm{SE}\right)$

\begin{tabular}{lccc}
\hline Steps/min $(n)$ & Gurkha & British & Paired $t$ test \\
\hline $15(15)$ & $1 \cdot 5 \pm 1 \cdot 0$ & $2 \cdot 7 \pm 1 \cdot 0^{*}$ & \\
$20(15)$ & $-1 \cdot 3 \pm 1 \cdot 7$ & $0 \pm 1 \cdot 3$ & \\
$25(13)$ & $4 \cdot 0 \pm 2 \cdot 3$ & $-1 \cdot 0 \pm 2 \cdot 3$ & \\
$30(10)$ & $2 \cdot 5 \pm 1 \cdot 5$ & $-4 \cdot 8 \pm 1 \cdot 5^{* *}$ & $p<0 \cdot 01$ \\
\hline
\end{tabular}

Significantly different from zero: ${ }^{*} p<0 \cdot 05 ;{ }^{* *} p<0 \cdot 02$.

During exercise, the difference between energy expenditure at the third and final minutes of each test was highly variable in both groups (table 3). This index did not differ significantly from zero at any work rate among Gurkhas, suggesting that on average they achieved a steady state during the tests. British subjects showed some evidence of a significant delay in attaining a steady state at the first rate of stepping, though not at the other levels of exercise. Only at the work rate 30 ascents per minute did the groups differ significantly, though not apparently because of differences in the delay in attaining a steady state. The high variability of these estimates contrasts with that observed for $\mathrm{VO}_{2(6-3)}$ in cycle ergometry for 5 subjects at levels of work output below $100 \mathrm{~W}$ (Whipp and Wasserman 1972). In recovery trials for calibrating Oxylogs during cycle ergometry, Harrison, Brown and Belyavin (1982) occasionally found variations of $\pm 14 \%$ in errors calculated from individual minute measurements of $\mathrm{V}_{2}$. While estimates of energy expenditure at work are in practice likely to be made from multiple measurements of $\dot{\mathrm{O}}_{2}$, caution appears necessary in using Oxylog estimates of single minute energy expenditure to determine the attainment of a steady state during exercise.

At the stepping rates 15,20 and 25 ascents per minute, Gurkhas showed significantly lower energy expenditure than the British; but at 30 ascents per minute the difference was not significant (table 2). Net cost of stepping (energy expenditure-BMR) was therefore significantly lower in Gurkhas at the first three rates of stepping (table 4). Furthermore, the ratio of gross energy expenditure to BMR for the first two rates of stepping was lower in Gurkhas than in the British, though differences were not significant at the higher exercise levels (table 4). 
Table 4. A. Net energy cost of stepping (kJ.min $\left.{ }^{-1}\right)$. B. Ratio of gross energy cost of stepping to BMR. C. Net mechanical efficiency of stepping (\%) at different rates of work $(M \pm S E)$

\begin{tabular}{lrrr}
\hline Steps/min $(n)$ & Gurkha & British & Paired $t$ test \\
\hline A. $15(15)$ & $22 \cdot 2 \pm 1 \cdot 9$ & $31 \cdot 4 \pm 1 \cdot 5$ & $p<0 \cdot 01$ \\
$20(15)$ & $32 \cdot 6 \pm 1 \cdot 7$ & $41 \cdot 6 \pm 1 \cdot 5$ & $p<0 \cdot 01$ \\
$25(13)$ & $45 \cdot 8 \pm 1 \cdot 7$ & $51 \cdot 4 \pm 1 \cdot 7$ & $p<0 \cdot 05$ \\
$30(10)$ & $45 \cdot 8 \pm 3 \cdot 6$ & $53 \cdot 5 \pm 1 \cdot 7$ & \\
B. $15(15)$ & $5 \cdot 6 \pm 0 \cdot 5$ & $7 \cdot 6 \pm 0 \cdot 4$ & $p<0 \cdot 05$ \\
$20(15)$ & $7 \cdot 6 \pm 0 \cdot 4$ & $9 \cdot 7 \pm 0 \cdot 5$ & \\
$25(13)$ & $10 \cdot 2 \pm 0 \cdot 4$ & $11 \cdot 9 \pm 0 \cdot 7$ & \\
$30(10)$ & $10 \cdot 1 \pm 0 \cdot 7$ & $12 \cdot 2 \pm 0 \cdot 8$ & $p<0 \cdot 01$ \\
C. $15(15)$ & $23 \cdot 4 \pm 2 \cdot 5$ & $14 \cdot 9 \pm 0 \cdot 5$ & $p<0 \cdot 02$ \\
$20(15)$ & $19 \cdot 6 \pm 1 \cdot 4$ & $14 \cdot 9 \pm 0 \cdot 5$ & $p<0 \cdot 05$ \\
$25(13)$ & $16 \cdot 8 \pm 0 \cdot 6$ & $14 \cdot 9 \pm 0 \cdot 5$ & \\
$30(10)$ & $21 \cdot 3 \pm 2 \cdot 1$ & $17 \cdot 0 \pm 0.5$ & \\
\hline
\end{tabular}

Since the step test involves raising body mass through a fixed distance, the mechanical work performed can be expressed as a percentage of the energy expenditure incurred. The hypothesis that Gurkhas are more efficient than their British controls can therefore be tested using the formula for net mechanical efficiency:

$$
\mathrm{NME}=\frac{(\mathrm{Wt} \times 0.46 \times 9.8 \times N) / 60}{(\mathrm{EE}-\mathrm{BMR}) / 60} \times 100
$$

where $\mathrm{Wt}=$ body mass $(\mathrm{kg}), 0 \cdot 46=$ height of step $(\mathrm{m}), 9 \cdot 8=$ gravitational constant $\left(\mathrm{m} . \mathrm{s}^{2}\right), N=$ number of ascents per minute, and $\mathrm{EE}=$ gross energy expenditure per minute $(\mathrm{J})$. By this criterion, Gurkhas are significantly more efficient than the British at the first three rates of work by mean $64 \%, 34 \%$, and $13 \%$ respectively (table 4 ). The estimates of net mechanical efficiency in the British fall within the range of values expected at step tests (16\% CV 7-11\%) (Shephard, Allen, Benade, Davies, Prampero, Hedman, Merriman, Myhre and Simmons 1968), suggesting that the Gurkha values are relatively high for the first two and final levels of exercise. The data also suggest that there is a constant increment in energy expenditure for each increment in work rate in both groups; and therefore no difference in absolute efficiency was observed.

In activities involving major body movements, it is reasonable to expect that body weight will largely determine the observed energetic cost (Mahadeva et al. 1953). A plot of the net cost of stepping at 15 ascents per minute on body weight in the British shows a significant linear relationship $\left(y\left(\mathrm{~kJ} . \mathrm{min}^{-1}\right)=0.95 \mathrm{Wt}-32.75, r=0.796, p<0.01\right)$ (figure 1). By comparison, a study of 37 South Indian subjects performing a step test of 18 ascents per minute onto a single-riser $20 \mathrm{~cm}$ step also showed a linear relationship between the net energy cost of stepping and body weight $\left(y\left(\mathrm{kcal} . \mathrm{min}^{-1}\right)=0.075\right.$ Wt $-0.634, r=0.798, p<0.001$ ) (McNeill, Rivers, and Payne 1988). The comparable equation for the British $\left(y\left(\mathrm{kcal} . \mathrm{min}^{-1}\right)=0.23 \mathrm{Wt}-7 \cdot 86\right)$ appears to show a steeper rise with body weight, but the subjects of the Indian study were lighter $(50.6 \mathrm{SD} 9.9 \mathrm{~kg})$, shorter $(163.8 \mathrm{SD} 6.4 \mathrm{~cm})$ and older $(30.6 \mathrm{SD} 7.9 y)$ than the British subjects; and their levels of physical activity were probably somewhat more variable. Thus the difference between these findings may be partly a function of differences in body proportion as well as related to the different experimental conditions. 


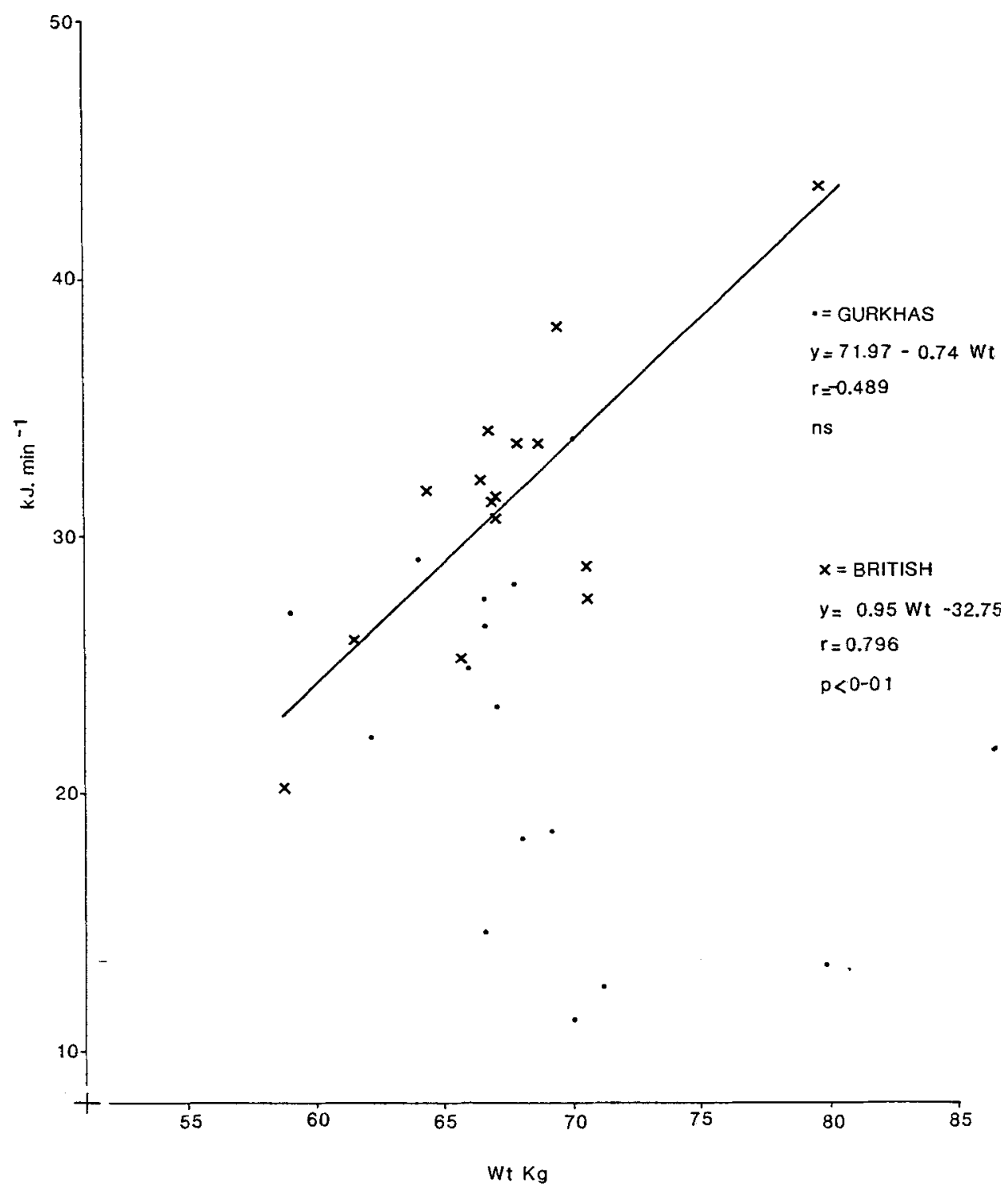

Figure 1. Net cost of stepping in Gurkhas $(\cdot)$ and British controls $(x)$ at 15 ascents per minute by body weight. A line is plotted where the correlation coefficient is significant in this and subsequent figures.

In contrast, the matched Gurkhas showed no relationship, although the slope of the regression is negative and differs significantly from that observed in the British $(t=4 \cdot 06, p<0 \cdot 001$ ) (figure 1). On removing the pair of heaviest individuals weighing about $80 \mathrm{~kg}$, the slopes of the two regression lines were found still to differ $(t=2 \cdot 581$, $p<0 \cdot 02$ ). A comparable plot for the stepping rate 20 ascents per minute shows a similar contrast in relationship between net energy cost and body weight in the two groups $(t=3 \cdot 24, p<0 \cdot 01)$, though the difference between slopes is not significant on removal of the heaviest pair of subjects $(t=1 \cdot 799,0 \cdot 05<p<0 \cdot 1)$ (figure 2 ). 


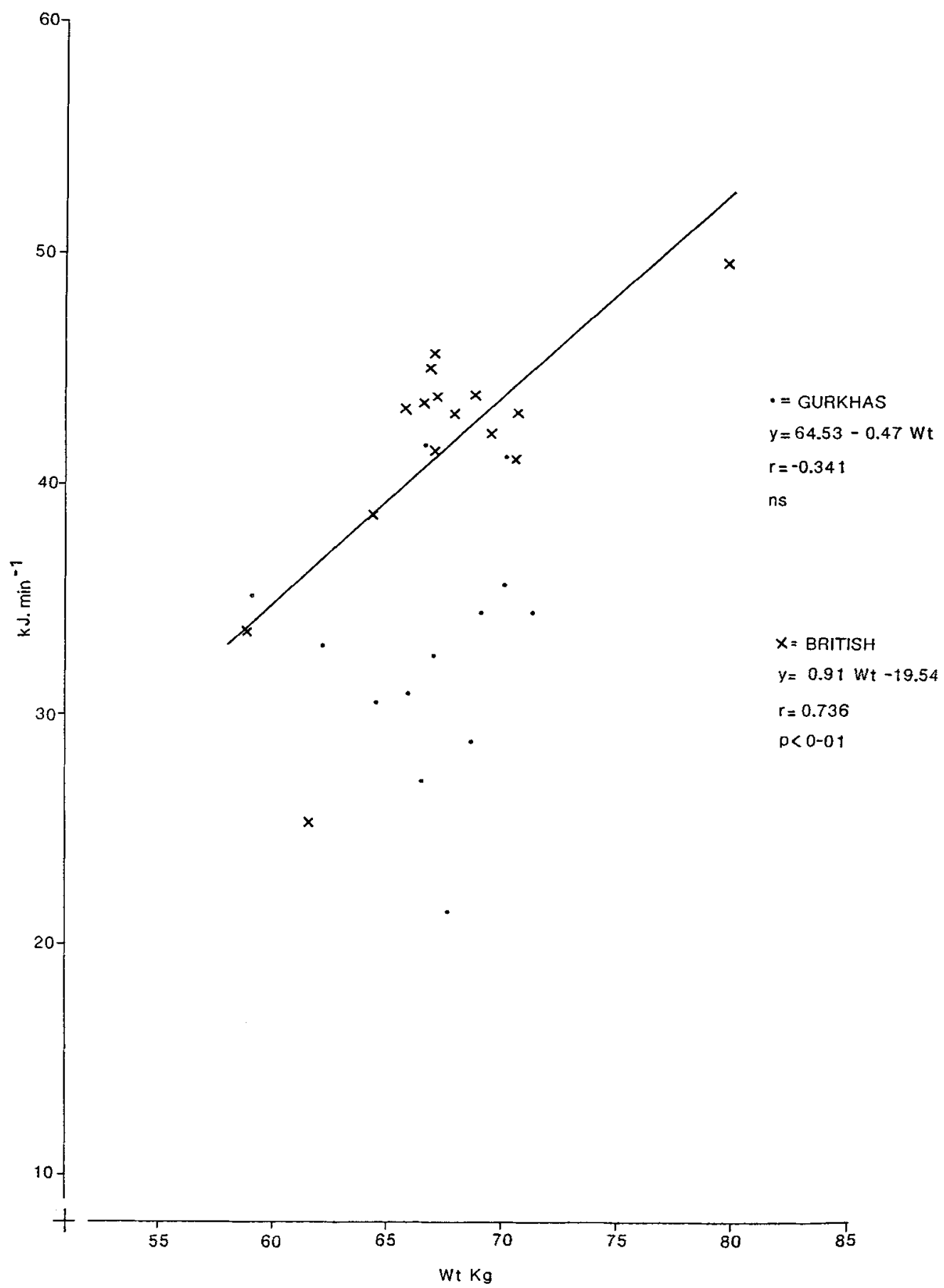

Figure 2. Net cost of stepping in Gurkhas (·) and British controls $(x)$ at 20 ascents per minute by body weight. 


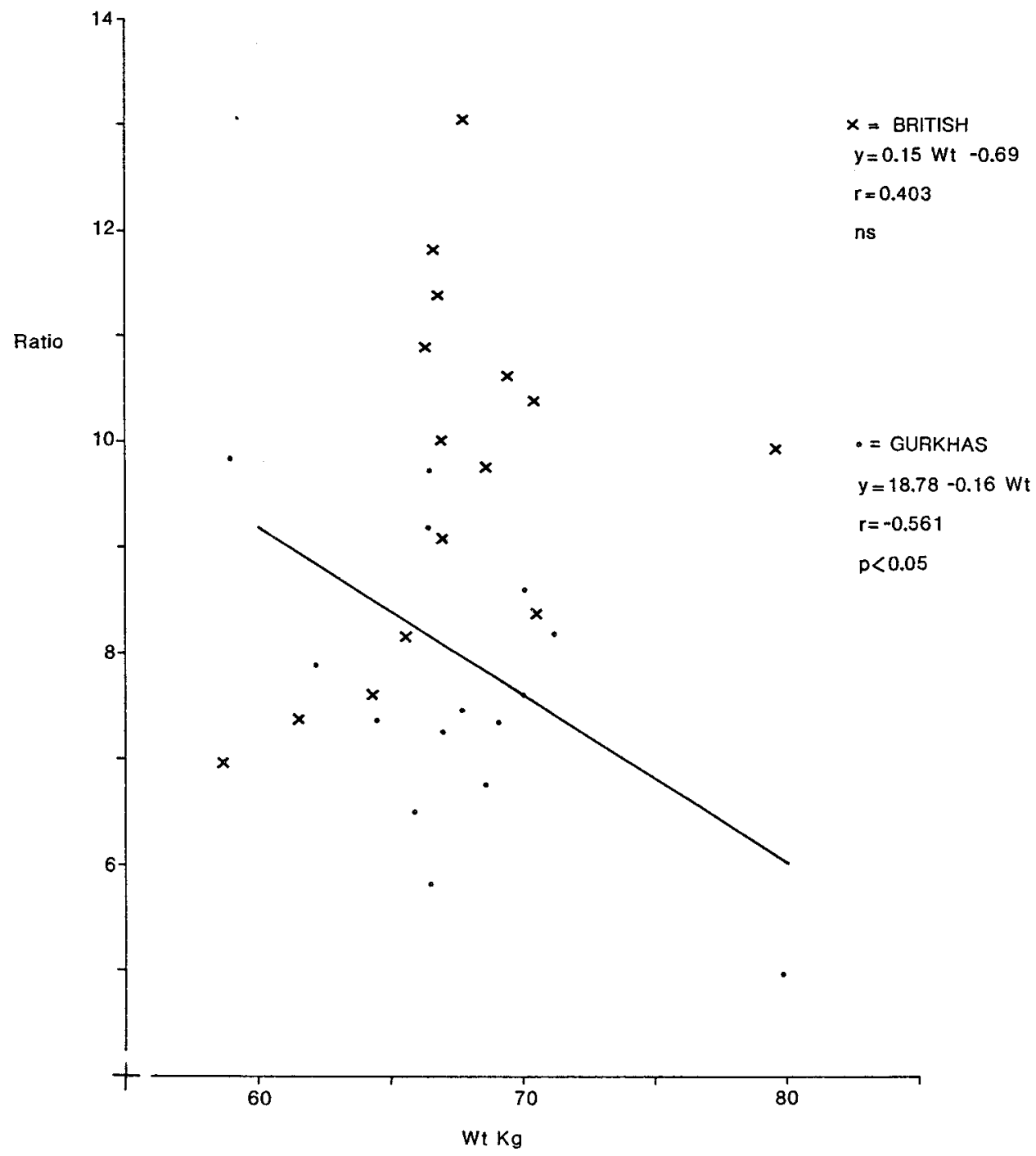

Figure 3. Ratio of gross energy expenditure to BMR at stepping at 20 ascents per minute by body weight in Gurkhas $(\cdot)$ and British controls $(x)$.

Gurkhas showed a lower ratio of gross energy expenditure to BMR at the two lower stepping rates compared with controls (table 4); and evidence from the South Indian study suggests that the ratio may show a positive linear correlation with body weight (McNeill et al. 1988). A plot of the ratio of cost of stepping to BMR on body weight, at a work rate of 20 ascents per minute, suggests for the British a wide scatter with no significant relationship (figure 3). For the Gurkhas, the plot suggests a negative correlation with body mass $(y=18.78-0.16 \mathrm{Wt}, r=-0.561, p<0.05)$ (figure 3 ). The slopes of the two regressions again differ significantly $(t=2.62, p<0.02)$ and this is not altered by removing the heaviest pair of subjects. However, the range of ratios within each group is considerable and no relationship was observed for these variables at the other work rates. Thus these findings do not agree with that of McNeill et al. (1988) that 
the ratio of cost of activity to BMR may not be independent of body weight. Studies on subjects with a wider range of body weights would be needed to determine whether such a relationship differs significantly across populations.

\section{Discussion}

Earlier studies of energy expenditure at stepping have shown a broad variation between individuals in the oxygen uptake required to perform a given work load at various speeds, and have suggested that this exercise test is suitable for investigating variation in muscular efficiency (Passmore and Thomson 1950). Compared to controls, poorly nourished Jamaicans have shown higher mechanical efficiency at step tests (Ashworth 1968); and Indonesians on low calorie intakes and with low BMR have shown higher mechanical efficiency at bicycle ergometry at $100 \mathrm{~W}$ output (though not $50 \mathrm{~W}$ ) than high calorie intake controls (Edmundson 1980). The values for the high intake group in the latter study are, however, low compared to those expected at cycle ergometry (Shephard et al. 1968; Norgan 1983). In a wider range of studies, there appears to be only tenuous evidence for increases in efficiency in groups experiencing low energy intakes; and more generally, non-Europeans exhibit mechanical efficiencies which are lower than European values, a phenomenon perhaps related to familiarity with the nature of the tests (Norgan 1983).

The Gurkhas investigated in this study, however, were familiar with step exercises, and they cannot reasonably be described as poorly nourished. It is probable, therefore, that some of the apparent difference in net energy cost of stepping and in net mechanical efficiency is to be explained by other factors. It is possible that the age difference, though slight, may have introduced a difference in training experience between the two groups. But the British controls were chosen from the same 5th Airborne Brigade to which the Gurkhas belong and had undergone comparable standard army training. Gurkhas were significantly shorter than the British subjects, most of the difference resulting from the greater leg length of the British, but the lower limb circumferences were larger in the Gurkhas. It is not known whether leg volume differs between the two groups; but if leg length were to explain the difference in energy cost of stepping, then for a given height of step it would be expected that those with shorter legs would incur a greater effort in the ascent, contrary to the findings of this study. Thus it is possible that variations in muscular development during growth in a Himalayan area of steep gradients (1:3) and at mid-altitude (1000-2000 m asl) may be related to differences in muscle composition between the two groups.

Tissue hypoxia may give rise to increased mitochondrial volume density and oxidative (but not glycolytic) enzyme activity in muscle at altitude (Ou and Tenney 1970) and after endurance training (Holloszy and Coyle 1984), but these changes affect maximal oxygen uptake rather than oxygen uptake at a given submaximal rate of work. However, maximum mechanical efficiencies (work/total enthalpy) of fast- and slowtwitch muscle fibres appear to differ, being estimated at $16 \%$ and $23 \%$ respectively (Wendt and Gibbs 1973). Gurkhas may therefore have a greater proportion of the slowtwitch, high-oxidative muscle fibres and resemble endurance athletes rather than sprinters in this respect (Holloszy and Coyle 1984) and in relative mechanical efficieney (Bunc, Sprynarová, Paĭzková and Leso 1984). While normal exercise training does not appear to convert one fibre-type into another and fibre-type distribution may be genetically determined, muscle phenotype characteristics may be modified or determined by thyroid hormone status (Nicol and Bruce 1981, Jolesz and Sreter 1981). Thyroid hormones in populations on low food intakes are suggested to mediate 
adaptive changes in resting energy expenditure (Osburne, Myers, Rodbard, Burman, Georges and O'Brian 1983, Millward 1986), and to determine interconversions of contractile and metabolic properties of fast- and slow-twitch muscles (Nwoye, Mommaerts, Simpson, Seraydarian and Marusich 1982). In addition, clinically hypothyroid patients show significant improvement in their energy economy compared with euthyroid controls during quadriceps muscle function tests (Wiles, Young, Jones and Edwards 1979). A possible mechanism for this effect is indicated by experimental studies showing that thyroid hormones influence the sequestration and release of calcium ion by the sarcoplasmic reticulum, and ATP consumption in calcium pumping during the contraction cycle, and therefore overall mechanical efficiency (Suko 1973, Limas 1982, Hardeveld and Clausen 1984). While there are no data on the thyroid hormone status of the subjects of this study, the Himalayas are a region of endemic goitre (Ward, Milledge and West 1989), and it is worth speculating that variations in thyroid hormone status during growth and development could have influenced the muscular efficiency of the Gurkhas.

Several factors may therefore have contributed to the greater apparent metabolic efficiency of the Gurkhas at stepping. It is also important, however, to note that BMR in Gurkhas showed some evidence of rising with the length of time since individuals had left Nepal (mean 8 months before the test, range 2-32 months). It would therefore be necessary to investigate the relation between net energy expenditure and body weight in Nepal in order to substantiate the finding of significant differences from the British in this respect.

Nonetheless, it seems clear from this study that it may not always be realistic to use constant multiples of BMR to express energy expenditure at standard activities in groups differing greatly in their habitats of origin and in their habitual activity patterns. It remains to be shown, however, whether multiples of BMR correlate with body weight according to the same relationship across populations.

\section{Acknowledgements}

The authors gratefully acknowledge the cooperation of volunteers from the 6 th Queen Elizabeth's Own Gurkha Rifles and the 23rd Parachute Field Ambulance of the 5th Airborne Brigade, and their Commanding Officers Lieutenant Colonel J.A. Anderson and Lieutenant Colonel L.P. Lillywhite. They also thank Dr Chris Gooderson and Dr Andrew Duggan of the Army Personnel Research Establishment for advice and logistical support, and Prof. P. R. Payne, Dr N. G. Norgan, and Dr D. J. Millward for helpful comments. They also thank Malcolm Cox, Jim Vinter, and Dr I. A. Macdonald for technical assistance. The authors gratefully acknowledge the support of the Ministry of Defence during this study.

\section{References}

ARmitage, P., 1971, Statistical Methods in Medical Research (Oxford: Basil Blackwell), pp. 281-282.

AsHworTh, A., 1968, An investigation of very low calorie intakes reported in Jamaica. British Journal of Nutrition, 22, 341-355.

Bunc, V., SPrynarová, Š., Paǩizková, J., and Leso, J., 1984, Effects of adaptation on the mechanical efficiency and energy cost of physical work. Human Nutrition: Clinical Nutrition, 38C, 317-319.

EDMUNDSON, W., 1980, Adaptation to undernutrition: how much food does man need? Social Science and Medicine, 14D, 119-126.

FAO/WHO/UNU, 1985, Energy and Protein Requirements (Geneva: World Health Organisation), p. 38.

GeISSLER, C.A. and Aldouri, M.S.H., 1985, Racial differences in the energy cost of standardised activities. Annals of Nutritional Metabolism, 29, 40-47.

HARDEVEld, C. VAN, and Clausen, T., 1984, Effect of thyroid status on $\mathrm{K}^{+}$-stimulated metabolism and ${ }^{45} \mathrm{Ca}$ exchange in rat skeletal muscle. American Journal of Physiology, 247, E421-430. 
Harrison, M. H., Brown, G. A., and Belyavin, A. J., 1982, The 'Oxylog': an evaluation. Ergonomics, 25(9), 809-820.

HeNRY, C. J.K., and ReES, D.G., 1988, A preliminary analysis of basal metabolic rate and race. In Comparative Nutrition, edited by K. Blaxter and I. Macdonald (London: John Libbey), pp. 149-159.

Holloszy, J., and CoYle, E.F., 1984, Adaptations of skeletal muscle to endurance exercise and their metabolic consequences. Journal of Applied Physiology, 56(4), 831-838.

Jolesz, F. and SRETER, F.A., 1981, Development, innervation, and activity-pattern induced changes in skeletal muscle. Annual Review of Physiology, 43, 531-552.

LIMAS, C.J., 1978, Calcium transport ATPase of cardiac sarcoplasmic reticulum in experimental hyperthyroidism. American Journal of Physiology, 235, H745-751.

Mahadeva, K., Passmore, R., and Woolf, B., 1953, Individual variations in the metabolic cost of standardized exercises: the effects of food, age, sex and race. Journal of Physiology, 121, 225-231.

Maloiy, G. M. O., Heglund, N. C., Prager, L. M., Cavagna, G. A. and Taylor, C. R., 1986, Energetic cost of carrying loads: have African women discovered an economic way? Nature, 319, 668-669.

MCLEAN, J. A., 1984, Heat production or oxygen consumption? In Human Energy Metabolism, edited by A. J.H. van Es (Wageningen: Euro Nut report no. 5), 187-189.

Mclean, J.A. and ToBin, G., 1987, Animal and Human Calorimetry (Cambridge: University Press), pp. 261-274.

MCNeill, G., Cox, M.D. and Rivers, J.P. W., 1987, The Oxylog oxygen consumption meter: a portable device for measurement of energy expenditure. American Journal of Clinical Nutrition, 45, 1416-1419.

MCNeill, G., Payne, P. R. and Rivers, J.P. W., 1988, Patterns of Adult Energy Nutrition in a South Indian Village (London: Department of Human Nutrition, London School of Hygiene and Tropical Medicine, Occasional Paper no. 11), p. 62.

MillwARD, D. J., 1986, Hormonal responses to low intakes in relation to adaptation. In Proceedings of the XIII International Congress of Nutrition, edited by T. G. Taylor and N. G. Jenkins (London: John Libbey), 419-423.

NiCOL, C. J.M. and BRUCE, D.S., 1981, Effect of hyperthyroidism on the contractile and histochemical properties of fast and slow twitch skeletal muscle in the rat. Pfiugers Archiv, 390, 73-79.

Norgan, N. G., 1983, Adaptations of energy metabolism to level of energy intake. In Energy Expenditure under Field Conditions, edited by J. Paĭizková (Prague: Charles University), pp. 56-64.

Nwoye, L., Mommaerts, W.F.H.M., Simpson, D.R., Seraydarian, K. and Marusich, M., 1982, Evidence for a direct action of thyroid hormone in specifying muscle properties. American Journal of Physiology, 242, R401-408.

Osburne, R. C., Myers, E. A., Rodbard, D., Burman, K. K., Georges, L. P. and O'Brian, J. T., 1983, Adaptation to hypocaloric feeding: physiologic significance of the fall in serum $T_{3}$ as measured by the pulse wave arrival time (QKd). Metabolism, 32(1), 9-13.

OU, L. C., and TENNEY, S. M., 1970, Properties of mitochondria from hearts of cattle acclimatized to high altitude. Respiration Physiology, 8, 151-159.

Passmore, R. and Thomson, J. G., 1950, Energy expenditure during stepping. British Journal of Social Medicine, 4, 234-237.

Shephard, R. J., Allen, C., Benade, A. J.S., Davies, C. T. M., Prampero, P.E. di, Hedman, R., Merriman, J.E., MYhre, K. and Simmons, R., 1968, Standardization of submaximal exercise tests. Bulletin of the World Health Organisation, 38, 765-775.

SheTTY, P.S. and SoARES, M.J., 1988, Variability in basal metabolic rates of man. In Comparative Nutrition, edited by K. Blaxter and I. Macdonald (London: John Libbey), 141-148.

SUKO, J., 1973, The calcium pump of cardiac sarcoplasmic reticulum. Functional alterations at different levels of thyroid state in rabbits. Journal of Physiology, 228, 563-582.

Ulijaszek, S. J. and Strickland, S.S., 1989, Physique and basal metabolic rate of Gurkha soldiers serving in Britain. Abstract in Proceedings of the Nutrition Society, 48(2), $128 \mathrm{~A}$.

Ward, M.P., Milledge, J.S. and WeSt, J. B., 1989, High Altitude Medicine and Physiology (London: Chapman and Hall Medical), p. 302.

Weiner, J.S. and Lourie, J. A., 1981, Practical Human Biology (London: Academic Press).

WENDT, I. R. and GiBBS, C.L., 1973, Energy production of rat extensor digitorum longus muscle. American Journal of Physiology, 224(5), 1081-1086.

WhIPP, B. J. and WASSERMAN, K., 1972, Oxygen uptake kinetics for various intensities of constant-load work. Journal of Applied Physiology, 33(3), 351-356.

Wiles, M.P., Young, A., JonES, D.A. and EDWARDS, R. H. T., 1979, Muscle relaxation rate, fibre-type composition and energy turnover in hyper- and hypo-thyroid patients. Clinical Science, 57, 375-384.

Address for correspondence: Dr S. S. Strickland, Department of Public Health and Policy, London School of Hygiene and Tropical Medicine, Keppel Street, London WC1E 7HT. 
Zusammenfassung. Messungen der basalen metabolischen Ziffer und des Energieverbrauchs beim Liegen, Sitzen, Stehen und Absolvieren eines Stufentests mit vier Übungsebenen wurden bei GurkhaSoldaten, die in England stationiert sind, durchgeführt, und bei englischen Kontrollen mit angepaßtem Körpergewicht und Berufshintergrund. Es gab keinen signifikanten Unterschied der BMR, auch nicht bei den Energieskosten beim Liegen, Sitzen und Stehen zwischen den beiden Gruppen. Gurkhas zeigten einen signifikant niedrigeren gesamten und Nettoenergieverbruach, und damit eine signifikant größere mechanische Effizienz bei den niedrigeren Ebenen der Stufenübung. Das Verhältnis des gesamten Energieverbrauchs zu BMR war bei Gurkhas niedriger bei den untersten Ziffern der Stufen im Verleich mit den britischen Kontrolln. Diese Ergebnisse legen nahe, daß die Energieskosten einiger körperlicher Aktivitäten als Ausdruck eines vielfachen der BMR nicht über die Population gleich zu sein braucht.

Résumé. Des mesures du taux métabolique basal et des dépenses énergétiques en position couchée, assise, debout et au cours d'un "step test" à quatre niveaux d'effort, ont été effectuées chez des soldats Gurkha stationnés en Angleterre et sur des contrôles britanniques, assortis en fonction du poids et de l'activité professionnelle antérieure. Il n'y a pas de différence significative du métabolisme de base, ni du cout eńergétique des positions couchée, assise et debout entre les deux groupes. Les Gurkha montrent une dépense énergétique brute et nette significativement plus basse et par conséquent une efficience mécanique nette significativement plus élevée aux niveaux les plus bas du step test. le rapport de la dépense d'énergie brute, au métabolisme de base est plus basse chez eux aux rythmes de stepping les plus lents. Ces résultats suggèrent que le coût énergétique d'activités physiques, exprimé sous forme multiples du taux métabolique basal, peut ne pas être constant d'une population à une autre. 